\title{
MAHASISWI HIJABERS
}

\section{(Studi Living Qur’an tentang Pemahaman Jilbab Menurut Mahasiswi IQT)}

\author{
Muhamad Arpah Nurhayat \\ Fakultas Ushuluddin dan Pemikiran Islam UIN Raden Fatah Palembang \\ syahdan.muhammad08@gmail.com
}

\begin{abstract}
The rule of wearing veil is set by Allah in Al - Qur'an which aims to protect and keep off women from impaired lust and men's bad stare. In its implementation, most Muslim women have different styles in wearing it. The difference caused by their difference of understanding and point of views as to veil. As if to support the difference, every Ulama has different perception about women's aurat limitation. The difference veil implementation is happened as well on IQT's female students of Ushuluddin and Islamic Thought Faculty. This difference occurs because some factors like family, campus environment, boarding house, and their own understanding toward meaning and veil's goal.
\end{abstract}

Keywords: Aurat, Veil, Woman, IQT

\begin{abstract}
Abstrak : Aturan mengenakan cadar diatur oleh Allah di Al-Qur'an yang bertujuan untuk melindungi dan menjauhkan wanita dari gangguan nafsu dan tatapan buruk pria. Dalam implementasinya, sebagian besar wanita Muslim memiliki gaya yang berbeda dalam memakainya. Perbedaannya disebabkan oleh perbedaan pemahaman dan sudut pandang mereka sebagai cadar. Seolah-olah untuk mendukung perbedaan, setiap Ulama memiliki persepsi yang berbeda tentang batasan aurat perempuan. Perbedaan penerapan jilbab juga terjadi pada siswa perempuan IQT dari Ushuluddin dan Islamic Thought Faculty. Perbedaan ini terjadi karena beberapa faktor seperti keluarga, lingkungan kampus, rumah kost, dan pemahaman mereka sendiri terhadap makna dan tujuan cadar.
\end{abstract}

Kata Kunci : Aurat, Jilbab, Perempuan, IQT, 


\section{A. Pendahuluan}

Pakaian merupakan identitas manusia, ia membedakan antara satu individu dengan individu lainnya, bahkan antara satu masyarakat dengan masyarakat yang lain. Salah satu fungsi pakaian adalah untuk menutup aurat, Islam memberikan perbedaan yang sangat signifikan antara aurat pria dan wanita. ${ }^{1}$ Pendapat mayoritas Ulama bahwa aurat laki-laki ialah dari pusar hingga lutut sedangkan aurat perempuan adalah seluruh tubuhnya kecuali wajah dan telapak tangan. ${ }^{2}$

Jilbab sebagai sebuah trend dan fashion telah di terima oleh masyarakat luas, perkembangan jilbab sendiri dengan berbagai macam gaya dan model telah mendorong kaum hawa untuk menjadikan jilbab pakaian sehari-hari mulai dari ibu-ibu, para remaja, dan anakanak. ${ }^{3}$ Hal ini juga terjadi dikalangan mahasiswi di kampus.

Di UIN Raden Fatah Palembang kampus mewajibkan kepada seluruh mahasiswi untuk menutup aurat sebagai lambang dari kampus Islam, peraturan ini nampaknya diterjemahkan dengan bermacam cara oleh para Mahasiswi, dari pengamatan kami ada mahasiswi yang memakai jilbab yang sangat longgar tanpa menutup wajah mereka, ada juga mahasiswi yang memakai jilbab yang agak ketat dengan rok yang juga ketat, ada juga yang memakai jilbab lengkap dengan penutup wajah/cadar. Waktu pemakaiannya pun berbeda-beda, ada yang memakainya hanya ketika di dalam area kampus saja tetapi di luar kampus dan area kos mereka (yang cenderung sangat dekat dengan kampus) mereka tidak memakainya. Ada yang konsisten dalam memakai jilbab baik di kampus atau di luar kampus. Ada juga mahasiswi baru memakai jilbab sekitar seratus meter dari lingkungan kampus sehingga disebut Jilbab Seratus Meter (ISMET) Kejadian ini sangat ironis mengingat banyak Muslimah di negeri Iain harus berjuang keras untuk mendapat hak berjilbab di sekolah atau kampusnya.

Fenomena di atas terjadi hampir di seluruh fakultas dan jurusan di lingkungan UIN Raden Fatah Palembang tidak kecuali jurusan Ilmu Quran dan Tafsir (IQT) Fakultas Ushuluddin dan Pemikiran Islam, hal ini sangat menarik mengingat mahasiswi yang ada di jurusan ini terkesan lebih paham dan mengerti mengenai anjuran dan cara menutup aurat dibandingkan dengan jurusan-jurusan lain yang ada di UIN. Mungkin pendapat ini sangat prematur tetapi paling tidak kesan tersebut terbentuk karena kurikulum yang disajikan kepada mereka yang sangat banyak mempelajari ilmu-ilmu ke Islaman termasuk pelajaran mengenai Alquran.

\footnotetext{
${ }^{1}$ M. Quraish Shihab, Jilbab pakaian wanita Muslimah (Jakarta, Lentera Hati, 2014) h. 34

${ }^{2}$ Felix Y Siaw, Yuk Berhijab! Hijab tanpa nanti, Taat tanpa Tapi (Bandung: Mizan, 2013) h. 53

${ }^{3}$ Nova Yohan, Konstruksi Jilbab sebagai symbol keislaman, Jurnal mediator, Vol 8, No. 2.
} 
Berdasarkan latar belakang di atas, kami tertarik untuk meneliti tentang bagaimana cara berjilbab mahasiswi Ilmu Quran dan Tafsir (IQT) Fakultas Ushuluddin dan Pemikiran Islam UIN Raden Fatah Palembang untuk menutup aurat mereka.

\section{B. Jilbab Menurut Para Pakar.}

1. Menurut Ulama.

Jilbab adalah pakaian wanita Muslim, dalam Islam, berhijab diwajibkan bagi wanita untuk menjaga fitrah mereka, dalam Islam wanita memiliki kedudukan yang terhormat, dan diantara penghormatan Islam terhadap wanita adalah disyari'atkannya jilbab bagi para muslimah, dengan demikian para wanita muslimah tidak menjadi bahan tontonan laki-laki yang bukan mahramnya. Tentang hukum memakai jilbab sendiri telah menjadi perdebatan diantara pakar, ada yang pro dan kontra mengenai batas aurat yang harus ditutup. Menurut Nashiruddin al-Albani ada delapan syarat jilbab bagi wanita Muslimah: 1) Menutup seluruh badan kecuali yang diperbolehkan. 2) Bukan berfungsi sebagai perhiasan. 3) kainnya harus tebal. 4) harus longgar, tidak ketat sehingga menggambarkan sesuatu dari bentuk tubuhnya. 5) Tidak diberi wewangian atau parfum. 6) Tidak menyerupai pakain laki-laki. 7) Tidak menyerupai pakaian wanita non Muslim. 8) bukanlibas Syuhrah (pakaian popularitas).

Pendapat lainnya adalah menurut konsep fiqh, K.H Ali Yafie dalam buku Menggagas Fiqih Sosial menyatakan bahwa dalam penalaran fiqih dalam soal pakaian, menitik beratkan pada fungsinya dalam etika pergaulan keluarga dan masyarakat ramai, dan inilah yang merupakan soal pokoknya. Bahannya, bentuknya dan modelnya merupakan wasilah atau sarana untukmewujudkan fungsi itu. Oleh karena itu, busana perempuan yang beriman tidakterikat pada bentuk atau mode, bahan dan warna dari jilbab di zaman awal, tetapidapat berkembang dalam batas-batas fungsi, etika dan estetika yang dibenarkan oleh hukum Islam, yang memungkinkan ia berubah dari zaman ke zaman. ${ }^{4}$

Hampir seluruh Ulama salaf berpendapat bahwa wanita harus menutup seluruh tubuhnya kecuali wajah dan telapak tangan, Husein Shahab berpendapat bahwa jilbab adalah suatu hukum yang pasti dan tegas yang mana seluruh wanita muslimah diwajibkan untuk mengenakannya.Melanggar atau tidak mematuhinya berarti telah mengingkari salah satu hukum Islam yang esensial. ${ }^{5}$ Hal yang sama juga diungkapkan oleh Bakar bin "Abdullah Abu Zaid, bahkan tokoh yang kedua ini lebih ekstrim dalam memandang jilbab, ia mengatakan bahwa

\footnotetext{
${ }^{4}$ Alie Yafie, Menggagas Fiqh Sosial dari soal lingkungan hidup, asuransi hingga ukhuwah (Jakarta: Mizan, 1994), h 252.

${ }^{5}$ Husein shahab, Jilbab Menurut Alquran dan as-Sunnah (Bandung: Mizan, 2005), h 8.
} 
wanita wajib menutup wajah dan kedua telapak tangannya apabila berada di luar rumah atau bertemu dengan laki-laki yang bukan muhrimnya. ${ }^{6}$

Al-Maraghiy memaknai jilbab sebagai baju kurung yang meliputi seluruhtubuh perempuan, lebih dari sekedar baju biasa dan kerudung.Mengutip IbnMandzur dalam Lisan al Arab, pengertian jilbab yang lazim adalah berupaselendang atau pakaian lebar yang dipakai kaum wanita untuk menutupi kepala, punggung, dan dada. Sedangkan Imam Raghib dalam AlMufradat Fii Gharib mengartikan jilbab sebagai pakaian longgar yang terdiri dari baju panjang dankerudung yang menutupi badan, kecuali wajah dan telapak tangan. ${ }^{7}$ Bila beberapa tokoh agama diatas lebih memandang jilbab dari segi besarnya pakaian yang harus dikenakan, maka Muhandy Ibn.Haj lebihmemberikan gambaran mengenai persyaratan yang harus dipenuhi sehingga jilbabsah untuk dipakai. Beberapa syarat tersebut yaitu :

1. Busana (jilbab) yang menutupi seluruh tubuhnya selain yang dikecualikan. Bagian yang dikecualikan ini meliputi muka dan telapak tangan sesuai dengan ketentuan beberapa hadis dari Nabi Muhammad SAW.

2. Busana yang bukan untuk perhiasan kecantikan atau tidak berbentuk pakaian aneh, menarik perhatian, dan tidak berparfum (wangi-wangian).

3. Tidak tipis sehingga tampak bentuk tubuhnya.

4. Tidak sempit sehingga tampak bentuk tubuhnya.

5. Busana yang tidak menampakan betisnya (kaki) atau celana panjangyang membentuk kakinya dan kedua telapak kakinya pun harus tertutup.

6. Tidak menampakan rambutnya walau sedikit dan tidak pula lehernya

7. Busana tidak menyerupai pakaian laki-laki dan tidak menyerupai pakaian wanita-wanita kafir yang tidak islami. ${ }^{8}$

Perbedaan pandangan para ulama soal busana perempuan ini sangat dipengaruhi oleh perbedaan pandangan tentang batas-batas aurat yang harusditutupi perempuan.Untuk mengkaji permasalahan tersebut, kita mulai denganmenelusuri arti kata jilbab itu sendiri.Kata jilbab berasal dari kata kerja "jalaba"dalam bahasa Arab yang bermakna "menutup sesuatu dengan sesuatu yang lainsehingga tidak dapat dilihat.”Dari pengertian tersebut, secara spesifik masihbanyak ulama yang berbeda pendapat tentang pengertian jilbab.Sebagianpendapat mengatakan jilbab itu mirip Rida' (sorban), sebagian lagi mendefinisikannya dengan kerudung yang lebih besar dari

\footnotetext{
${ }^{6}$ Bakar bin 'Abdullah Abu Zaid, Menjaga Kehormatan terj. Gunaim Ihsan (Jakarta: As-Shofwa, 2003), h 30-33.

${ }^{7}$ Muhammad Shahrur, al-Kitab wa al-Qur'an: Qira'ah Mu'ashirah, h 247.

${ }^{8}$ Kusumayadi.; Amir Taufik, Enam Puluh Satu Tanya Jawab Mengenai Jilbab (Kuala Lumpur: Pustaka Jasmin, 1989), h 18.
} 
Khimar.Khimar adalah istilah umum untuk pakaian penutup kepala dan leher.Sebagian lagi mengartikannya dengan Qina yaitu penutup muka atau kerudung lebar. ${ }^{9}$

Dari berbagai pengertian diatas, dapat dipahami bahwa ulama sepakat akan wajibnya menutup aurat bagi laki-laki dan perempuan, namun mereka berbeda pendapat tentang batas aurat tersebut, salah satu cara menutup aurat adalah dengan memakai jilbab, dan ternyata pengertianjilbab tidaklah tunggal. Berbagai pijakan digunakan untuk mendefinisikan danmemaknai jilbab sebagai pakaian perempuan muslimah.Masing-masing pijakanmempunyai hukum atau landasan tersendiri berdasarkan faktor asal mula jilbab dan konteks yang mengiringi turunnya jilbab. Perbedaan pandangan tersebut lebihdisebabkan adanya perbedaan cara atau metode menginterpretasikan teks (nash)baik dari hadis Nabi Muhammad maupun dari Al-Quran. Akibatnya,dalam Islamterdapat dua perspektif berkaitan dengan hukum mengenakan jilbab.

\section{Menurut Cendikiawan.}

Dalam Islam Jilbab merupakan pakaian perempuan, apabila kita merujuk kepada ensiklopedi hukum Islam, pakaian adalah sesuatu atau barang yang dipakai oleh manusia di badan. Pakaian merupakan sesuatu yang harus bagi laki-laki dan perempuan, sebab ia merupakan pelindung yang dibutuhkan oleh kesehatan, ia juga merupakan penutup yang melindungi sesuatu yang menyebabkan malu apabila terlihat oleh orang lain dan ia merupakan perhiasan yang disukai oleh fitrah tanpa beban. ${ }^{10}$ Jilbab dalam ensiklopedi ini diartikan sebagai baju kurung lapang yang dapat menutup kepala, muka, dan dada.

Menurut Fadwa El Guindi, jilbab jika diistilahkan dalam bahasa Inggris bukan hanya sekedar seperti scarf (semacam selendang atau syal), melainkan dapat diistilahkan dengan veil (atau voile dalam bahasa Perancis) yang biasa dipakai untuk merujuk pada penutup kepala tradisional, wajah atau tubuh wanita di Timur Tengah dan Asia Selatan ${ }^{11}$. Sedangkan di Indonesia, jilbab kerap disamakan pengertiannya dengan hijab, yang dimaknai sebagai pakaian longgar, atau kerudung (simple handscarf). Bahkan bagi El Guindi, jilbab di Indonesia dapat merujuk pada corak pakaian Islam namun seringkali maknanya tidak konsisten. Dalam hal ini jilbab bukan hanya sebagai penutup kepala saja, melainkan menjadi kesatuan dengan pakaian yang digunakan seorang perempuan muslim.

Namun jika dilihat dalam konteks sejarah perkembangan agama, konsep hijab atau jilbab sebenarnya bukan hanya milik Islam, karena dalam beberapa kitab sebelumnya (kitab Taurat),

\footnotetext{
${ }^{9}$ Kusumayadi.; Amir Taufik, Enam Puluh Satu Tanya Jawab Mengenai Jilbab, h 26.

${ }^{10}$ Abdul Aziz Dahlan, Ensiklopedi Hukum Islam (Jakarta: Ichtiar Baru, 1993), h. 167.

${ }^{11}$ Fadwa El Guindi, Jilbab; Antara Kesalehan, Kesopanan dan Perlawanan (Jakarta: Serambi, 2008), h.
} 
ataupun kitab suci agama Yahudi, juga dikenal beberapa istilah yang semakna dengan hijab yaitu tif'eret. Demikian pula dalam kitab Injil, ditemukan istilah semakna, dengan sebutan zammah, re'alah, zaif, dan mitpahat ${ }^{12}$.Bahkan menurut Nasarudin Umar (Universitas Islam Negeri, Jakarta), hijab dalam arti penutup kepala sudah dikenal sebelum adanya agama-agama Samawi (Yahudi dan Nasrani).Tradisi penggunaan kerudung juga telah dikenal dalam hukum kekeluargaan Asyiria.Dengan demikian, jilbab ataupun hijab memiliki istilah yang sebenarnya bukan hanya merupakan masalah sederhana, karena jilbab memiliki pengertian antara pakaian wanita (aspek tubuh) dan lintas budaya.Dalam hal ini, meski secara mendasar jilbab dapat diartikan sebagai kain yang digunakan untuk menutup kepala perempuan, namun dalam konteks kemasyarakatan, jilbab juga menyuguhkan pada dua sisi yang dapat menjadi berbeda dan saling bertentangan. Di satu sisi terdapat upaya pelarangan, dan di sisi lain ada upaya pemaksaan atau keharusan dalam pemakaiannya.

Muhammad Syahrur seorang tokoh kontroversial dalam kitabnya "Alkitab wa al Qur'an: Qira'ah Mu'asyirah" juga membahas masalah hijab dengan menggunakan metode intertekstualitas dan dengan menggunakan pendekatan linguistik sintagmatis. Hasilnya, Syahrur mendapatkan pandangan yang berbeda dengan kebanyakan ulama dalam masalah hijab. Bagi Syahrur, kata al-khumur dalam Surat al-Nur: 31 tidak bermakna 'tutup kepala' seperti yang lazim diketahui, namun yang di maksud adalah segala macam penutup tubuh baik kepala maupun anggota badan yang lain. Dikaitkan dengan konsep Syahrur tentang al-hadd al-adna (batasan minimal) dan al-hadd al-a'la (batas maksimal), yang kemudian dibandingkan dengan hadis Nabi saw yangmenyatakan bahwa seluruh bagian tubuh wanita adalah aurat, maka dapatdisimpulkan bahwa bagian tubuh yang termasuk kategori al-juyub (lekuk tubuhyang mempunyai celah dan bertingkat; seperti bagian di antara kedua buah dada,di bawah buah dada, di bawah ketiak, kemaluan, dan kedua bidang pantat)adalahal-hadd al-adna. Adapun bagian tubuh seperti wajah, telapak tangan, dan telapakkaki adalah al-hadd al-a'la. Konsekuensinya, seorang wanita yang menutupseluruh anggota tubuhnya berarti ia telah melanggar hudud Allah, begitu jugawanita yang memperlihatkan tubuhnya lebih dari anggota yang termasuk kategori al-juyub. ${ }^{13}$

Menurut Said Ramadhan al-Buti, Islam mewajibkan kepada perempuan untuk berhijab karena di dunia ini banyak terjadi interaksi sosial antara kaum laki-laki dan perempuan, interaksi dan kerjasama ini tidak dapat dihindari karena mereka sama-sama bertanggung jawab atas kemajuan dan pembangunan masyarakat dan peradaban. Interaksi tersebut seringkali membawa

\footnotetext{
${ }^{12}$ Nong Darol Mahmadah, Kritik Atas Jilbab menurut Muhammad Said Al-Asymawi,h. 20.

${ }^{13}$ Muhammad Shahrur, al-Kitab wa al-Qur'an: Qira'ah Mu'ashirah (Kairo dan Damaskus: Sina lil al- Nasr, 1992), h. 245
} 
kepada hal yang negatif apabila potensi-potensi fitnah antara dua manusia yang berbeda jenis ini tidak diberlakukan syarat-syarat yang membuat kedua belah pihak saling menjaga dan menghormati kesucian mereka, salah satu syarat tersebut adalah menutup aurat (dengan memakai jilbab/hijab bagi perempuan). ${ }^{14}$

Al-Buthi mengkritik pendapat beberapa pakar yang mengatakan bahwa tujuan menggunakan jilbab adalah untuk mendidik wanita berakhlak dan mejauhkan dirinya dari dekadensi moral, asumsi ini menurutnya dijadikan sebagai himah dari pensyariatan jilbab bagi kaum Muslimah, kemudian ketika mereka menemukan seorang Muslimah berjilbab yang tidak terpuji akhlaknya, mereka mengkritik hikmah ini dan mengatakan bahwa tidak ada korelasi antara pendidikan jiwa yang ditimbulkan dengan cara atau mode berpakaian seseorang, mereka beranggapan bahwa perempuan yang terdidik dan berakhlak mulia tidak akan lari dari akhlaknya walaupun ia menggunakan pakaian yang sopan, sebaliknya perempuan yang tidak baik akhlaknya tidak akan bisa menjadi baik walaupun menggunakan jilbab/hijab. ${ }^{15}$

Pendapat berbeda dikemukakan oleh Muhammad Sa'id al-Asymawi, menurutnya jilbab bukan merupakan sebuah kewajiban, bahkan lanjutnya tradisi berjilbab yang dilakukan oleh para Sahabat dan tabi'in lebih merupakan keharusan budaya dari pada ajaran agama.Karena itu menurut al-Asymawi memakai jilbab tidak memiliki konsekuensi iman-kafir, selama dasarnya tetap kesopanan dan kehormatan. ${ }^{16}$ Senada dengan ini Husein Muhammad mengatakan bahwa pemakain jilbab ditujukan untuk membedakan antara perempuan merdeka dan hamba sahaya, dikarenakan budak/hamba sahaya pada zaman sekarang ini hampir sudah tidak ada maka pemakaian jilbab harusnya tidak diwajibkan lagi karena illat hukumnya tidak ada, namun apabila ada yang ingin memakainya juga tidak dilarang. ${ }^{17}$

Nazira Zein seorang cendikiawan asal Lebanon mencoba melihat jilbab dari perspektif sosial, ia mencoba membandingkan antara jumlah muslimah yang berjilbab dan yang tidak memakai jilbab, ia mengatakan bahwa jumlah muslimah yang berjilbab tidak lebih dari beberapa

${ }^{14}$ Ramadhan Al-Buti menceritakan penglamannya menghadiri sebuah pertemuan akademik di Jerman, ketika salah satu perempuan Jerman dipanggil untuk menyampaiakan urainnya, seperti perempuan kebanyakan di Barat ia berpakaian sangat minim, dan setiap gerak-geriknya menjadi sorotan publik, pada saat itu menurut al-Buti hamper semua wajah pria di ruangan tersebut melihat dengan gejolak nafsu kepada perempuan tersebut dan melupakan orasi ilmiahnya yang bagus. Menurutnya ini adalah sebuah penghinaan kepada seorang perempuan dan penghinaan itu sendiri muncul karena perempuan itu sendiri yang tidak menutup hal yang rawan dalam tubuhnya. Menurutnya, seluruh Muslimah apabila berada diposisi perempuan Jerman tersebut pasti tidak akan mempertontonkan apapun kecuali ide-ide cemerlang yang mereka miliki, hal ini karena Islam sebagai agama mengharuskan umatnya untuk menutup aurat. Lihat Muhammad said Ramadhan al-Buthi, Perempuan: Dalam Pandangan Barat dan Islam Terj. Nuruddin (Yogyakarta, Suluh Press, 2005) h. 178-180.

${ }^{15}$ Muhammad said Ramadhan al-Buthi, Perempuan: Dalam Pandangan Barat dan Islam Terj. Nuruddin, h. 194.

${ }^{16}$ Muhammad Sa'id al-Asymawi, Kritik Atas Jilbab terj. Novriantoni Kahar ( Jakarta: Jaringan Islam Liberal, 2003) h. 15 .

${ }^{17}$ Husein Muhammad,Islam Agama Ramah Perempuan (Yogyakarta: LKIS, 2003), h. 215. 
juta yang tinggal di perkotaan, muslimat yang tinggal di pedesaan di dunia Islam lebih dari 1700 juta tidak berjilbab, mereka menoak jilbab yang sebelumnya mereka pakai. ${ }^{18}$ Lebih lanjut ia menyatakan bahwa Negara yang menolak jilbab adalah Negara-negara yang telah maju dari aspek intelektual dan materil, kemajuan tersebut tidaklah sama dengan Negara-negara yang memberlakukan jilbab kepada para wanitanya. Bangsa-bangsa yang tidak memberlakukan jilbab adalah mereka yang telah mampu menemukan rahasia-rahasia alam melalui hasil riset dan studi serta mampu menmpatkan unsur-unsur fisik di bawah kendali mereka.Di Negara yang muslimatnya memakai jilbab tidak mampu menggali rahasia-rahasia tersebut, mereka hanya mampu menyanyikan lagu-lagu tentang keagungan tradisi-tradisi kuno dan masa lalu, dan dengan nyanyian tersebut mereka terlelap di dalam kejumudan.Menurutnya di Barat perilaku orang sangat dipengaruhi dengan pendidikan yang tinggi dan pelajaran moral sehingga pemakaian jilbab atau tidak memakainya tidak mempengaruhi penghormatan laki-laki kepada perempuan.

Dari penjelasan di atas kita bisa mengambil kesimpulan bahwa berbeda dengan para ulama, cendikiawan ada yang menganggap jilbab merupakan ajaran yang harus dipatuhi dan memakainya menyebabkan kaum wanita terlindung dari gangguan dan gunjingan para laki-laki, namun ada juga yang menganggap bahwa jilbab hanya anjuran yang tidak bisa lepas dari ruang dan waktu, saat ayat tentang perintah memakai jilbab turun kita harus melihat kepada persoalan mengapa perintah itu diturunkan, ketika kita dihadapkan kepada zaman dimana kriminalisasi terhadap perempuan sudah tidak ada maka perintah berjilbab tersebut gugur dengan sendirinya. Demikian penjelasan sebagian cendikiawan mengenai jilbab.

\section{Jilbab Menurut Mahasiswi IQT}

Jilbab mahasiswi IQT Fakultas Ushuluddin dan Pemikiran Islam tidak berbeda dengan fakultas-fakultas lainnya, di sini juga terdapat keberagaman jilbab mulai dari pendek, sedang, dan dalam. Warna yang di pakai pun beragam, ada yang suka memakai warna gelap, ada juga yang terang, ada yang polos, dan ada yang mempunyai ,motif seperti bunga dan lambang organisasi.

Untuk mendalami pemahaman mereka tentang jilbab dan aplikasinya, peneliti melakukan wawancara, adapun teknik wawancara yang digunakan adalah etnografi, yaitu wawancara yang menggambarkan percakapan persahabatan yang bernuansa santai, teknik wawancara ini sangat berguna untuk mendapatkan data yang lengkap tanpa ditutup-tutupi oleh sampling yang di waancara, kesan non-formal membuat pewawancara dan yang diwawancarai lebih rileks dan

${ }^{18}$ Charlez Kurzman, Wacana Islam Liberal (Jakarta: Paramadina, 2003), h. 135-136. 
mampu mengelaborasi lebih dalam data yang diperlukan. Adapun dalam wawancara peneliti berusaha mengambil data-data yang peneliti anggap penting, data-data tersebut adalah:

a. Latar belakang keluarga responden, ini diperlukan untuk melihat sejauh mana keluarga mempengaruhi cara berjilbab responden

b. Suasana tempat tinggal responden, untuk melihat seberapa besar faktor lingkungan tempat tinggal terhadap cara berjilbab responden

c. Cita-cita dan tujuan masuk IQT, untuk melihat apakah ada singkronisasi antara jilbab dan cita-cita responden

d. Tanggapan responden selama kuliah di IQT, ini sangat penting untuk melihat apakah prodi IQT memiliki pengaruh terhadap sikap, kepribadian, dan cara berjilbab responden

e. Organisasi yang diikuti, melalui ini peneliti ingin melihat adakah faktor pergaulan di organisasi memberikan dampak bagi responden

f. Pemahaman responden terhadap jilbab, ini diperlukan untuk melihat apakah pemahaman memberikan pengaruh kepada jilbab yabg di pakai, serta adakah singkronisasi antara pemahaman dengan aplikasi.

g. Tokoh panutan dalam berjilbab, untuk melihat kemungkinan adanya faktor lain di luar keluarga, teman, dan dosen yang mempengaruhi cara berjilbab responden.

Hasil dari Wawancara dengan poin-poin di atas memberikan gambaran bahwa semua mahasiswi IQT memiliki pandangan yang positif terhadap jilbab, hampir semua dari mahasiswi melihat jilbab merupakan ajaran Islam yang wajib untuk di patuhi (walaupun tingkat kepatuhan mereka dalam memakai jilbab bermacam-macam), data yang di peroleh juga menegaskan bahwa masih ada beberapa orang mahasiswi IQT yang hanya memakai jilbab di dalam kampus dan melepasnya di luar kampus, namun jumlahnya tidak terlalu banyak apabila dibandingkan dengan mahasiswi dari prodi lainnya.

Dalam berjilbab mahasiswi IQT tidak lepas dari fashion, pengaruh warna jilbab dan motif masih kental dalam cara mereka berjilbab baik yang berjilbab dalam maupu tidak, semua mahasiswi ketika ditanya "apakah warna dan motif menjadi acuan saudari dalam membeli dan memakai jilbab?" mereka menjawa penting dan harus sesuai dengan warna baju yang kita pakai, kalau untuk motif dan gambar-gambar di jilbab itu juga bagus, yang penting tertutup. Hal ini tidak lepas dari kampanye fashion yang dilakukan oleh media baik cetak maupun elektronik, disamping itu umur mereka yang masih remaja juga berperan penting dalam tata cara mereka memilih warna jilbab, walaupun berjilbab, mereka juga ingin tampil cantik dan anggun. 
Mahasiswi IQT juga menolak pendapat yang mengatakan bahwa jilbab merupakan sebuah produk budaya yang datang dari Arab, bukan ajaran langit yang dating dari Allah SWT, walaupun argumentasi yang mereka kemukakan tidak begitu jelas dan tanpa data dan referensi dari buku-buku yang representatif. Hal ini dapat dilihat ketika mereka ditanya tentang "bagaimana menurut saudari tentang pendapat yang mengatakan bahwa jilbab merupakan budaya yang berasal dari Arab bukan ajaran Islan?”, seluruh mereka menjawab pendapat tersebut tidak benar dan berasal dari oknum-oknum yang ingin merusak ajaran Islam.

Pada dasarnya kewajiban menggunakan jilbab di dalam Islam bukan untuk membelenggu wanita, karena posisi sosial wanita di dalam Islam sama dengan pria, keduanya punya peranan masing-masing dalam ranah sosial meskipun berbeda karena peranan tersebut disesuaikan dengan kodratnya. Seorang intelektual Muslim bernama Mohsin Araki mengatakan bahwa baik perempuan maupun pria memiliki peranan, kewajiban, dan tanggung jawab terhadap masyarakat dimana mereka hidup. Keduanya memiliki kewajiban yang sama untuk melindungi masyarakat dari polusi dan kontaminasi. ${ }^{19}$

Hak-hak dan kewajiban yang diberikan Islam kepada kaum wanita bahkan sangat layak apabila dibandingkan dengan apa yang telah dilakukan oleh bangsa Yunani, umat Kristen pada abad pertengahan, Hindu, dan Yahudi, bahkan menurut Quraish Shihab Islam lebih toleran dalam memuliakan kaun wanita, ia mengatakan bahwa "masyarakat Yunani yang terkenal dengan pemikiran filsafatnya tidak terlalu banyak membicarakan hak dan kewajiban wanita. Di kalangan elite mereka, para wanita (disekap) di dalam istana, sedangkan di kalangan bawah nasib wanita sangat tragis karena menjadi budak yang diperjualbelikan, sedangkan yang sudah berumah tangga, mereka berada penuh di bawah kekuasaan suaminya. Peradaban Hindu dan Cina tidak jauh lebih baik, hak hidup wanita harus berakhir ketika suaminya meninggal, ia harus di bakar hidup-hidup bersama dengan jazad suaminya sebagai lambing kesetiaan, praktek yang menyedihkan ini baru berakhir pada abad ke 7 masehi. Dalam ajaran Yahudi pun demikian, seorang ayah berhak menjula anak perempuannya kalau ia tidak memiliki saudara laki-laki. Ajaran mereka menganggap bahwa wanita adalah sumber laknat dan malapetaka karena wanita (Hawa) yang mengakibatkan Adam terusir dari surga. Ada pun dalam pandangan sementara para pemuka agama Nasrani, menganggap wanita adalah senjata iblis untuk menyesatkan pria, pada abad ke 5 masehi diselenggarakanlah konsili untuk membahas apakah wanita mempunyai ruh atau tidak. ${ }^{20}$ Berbeda dengan ajaran-ajaran di atas, dalam Islam para

\footnotetext{
${ }^{19}$ Ali Hosein Hakim, Membela Perempuan: Menakar Feminisme dengan Nalar Agama (Jakarta: al-Huda, 2005)
} h. 42

${ }^{20}$ Quraish Shihab, Wawasan Al-Qur'an (Bandung: Mizan, 1997) h. 296-297. 
wanita memiliki hak dan tanggung jawab sesuai dengan kodrat kewanitaannya, seperti hak untuk bekerja dan belajar, istri seorang sahabat Nabi 'Abdullah bin Mas'ud yang bernama Raithah misalnya, sangat aktif bekerja (wanita karir) karena suami dan anak-anaknya tidak mampu dalam mencukupi kebutuhan keluarganya. Sementara itu juga ada perempuan yang pandai menulis bernama al-Syifa diberikan amanah oleh khalifah Umar bin Khattab untuk menjadi petugas menangani pasar di kota Madinah. Ini merupakan sebagian kecil contoh bahwa Islam menjunjung tinggi martabat wanita, dan perintah untuk memakai jilbab dalam Alquran tidak mungkin ditujukan untuk membelenggu wanita, melainkan ajaran untuk memberikan kemaslahatan terhadap umat manusia.

Mahasiswi IQT melihat bahwa jilbab tidak saja sebuah kewajiban karena mereka kuliah di prodi yang bergelut dengan Alquran dan hadis, tetapi ia juga sebuah kebutuhan untuk menjaga diri mereka dari hawa nafsu dan perilkau yang tidak baik, ketika ditanyakan "apa dampak jilbab bagi kepribadian saudari?", semua menjawab jilbab memberikan dampak positif bagi akhlak dan kepribadian mereka, dampak tersebut mulai dari menjaga diri dari pergaulan yang bebas dengan lawan jenis, menghindari perkataan bohong, menyebar gosip, menghormati orangtua, sampai dengan meningkatkan ibadah.

\section{Faktor-Faktor yang Mempengaruhi Cara Berjilbab Mahasiswi IQT.}

Dari 10 responden yang diwawancarai hanya dua orang yang memakai jilbab sejak duduk di bangku SMP/MTS sederajat, adapun 7 orang lainnya memakai jilbab sejak berada di bangku SMA/MA sederajat dan itu pun karena tuntutan dari sekolah. Hampir semua responden mengungkapkan bahwa jilbab adalah sebuah kewajiban bagi seluruh perempuan muslim, memakainya membuat kita terhindar dari godaan syahwat lelaki dan terjaga dari perbuatan yang tidak baik. Walaupun responden mengetahui makna dan urgensi berjilbab tapi tidak semua mereka mengimplementasikan pada diri mereka sendiri, itu semua di pengaruhi oleh banyak faktor, berikut adalah faktor-faktor yang mempengaruhi cara berjilbab mahasisi IQT fakultas Ushuluddin dan Pemikiran Islam:

\section{Faktor Keluarga.}

Keluarga memegang peranan penting di dalam pembembentukan individu sehingga system yang dibangun dalam keluarga akan menentukan keberfungsian keluarga dalam menjalankan perannya. Dalam hal ini orang tua adalah guru pertama untuk anak yang berperan sebagai teladan untuk perilaku-perilaku baik, orang tua adalah model yang sangat penting untuk anak karena anak memiliki pandangan yang tinggi terhadap orang tua dan memiliki keinginan untuk seperti mereka. keteladanan yang ditunjukkan orang tua tidak 
hanya berkaitan dengan bagaimana memperlakukan anak, tetapi juga bagaimana orang tua memperlakukan orang dewasa lain, memperlakukan orang lain yang bukan anggota keluarga (contoh teman, tetangga, bahkan orang asing), serta bagaimana menjalankan hidup. ${ }^{21}$

Keluarga memberikan pengaruh terhadap cara berjilbab mahasiswi IQT, hasil dari wawancara menunjukkan bahwa keluarga (khususnya kedua orangtua) berperan aktif dalam menentukan cara berpakaian anak-anak mereka. Walaupun ada 4 orang respoden mengatakan bahwa orangtua mereka menyerahkan sepenuhnya kepada individu masing-masing dalam berpakaian, namun dari hasil probing wawancara menunjukkan dukungan orangtua terhadap pakaian dan gaya jilbab yang di pakai oleh anak berpengaruh kepada anak itu sendiri. Pendapat ini diperkuat dengan data bahwa 8 dari 10 responden yang mendapat dukungan untuk berjilbab dari keluarga merasa nyaman dengan dukungan tersebut, mereka menjadi termotivasi untuk tetap istiqomah memakai jilbab karena melihat keluarga mereka senang dengan jilbab yang mereka pakai. Berbeda dengan dua responden yang tidak mendapatkan dukungan dari keluarga, mereka menjadi tidak bersemangat untuk berjilbab dan mencari dukungan dari faktor lainnya seperti teman-teman di kampus dan organisasi.

Pengaruh orangtua terhadap cara berpakaian anak tidak lepas dari fungsi mereka sebagai penanggung jawab keluarga menuju keluarga yang sakinah. Tanggung jawab ini tidak hanya diperankan oleh bapak atau ibu saja. Menurut Ainun Habibie, tesis yang ia ajukan terkait dengan membentuk keluarga sakinah adalah bahwa keluarga sakinah tidak bisa dibangun hanya oleh seorang ayah atau ibu saja, keduanya merupakan team work, mereka memiliki tanggung jawab yang sama dan harus bahu-membahu dan saling melengkapi untuk menciptakan keluarga sakinah, harmonis, sejahtera, dan taat kepada Allah SWT. Tesis yang kedua menurutnya menciptakan keluarga sakinah pada dasarnya adalah menggerakan proses dan fungsi-fungsi manajemen dalam kehidupan rumah tangga. Karena itu, selain tugas-tugas kodrati (mengandung dan menyusui), segala sesuatu yang menyangkut tugas-tugas menciptakan keluarga sakinah haruslah fleksibel, terbuka, dan demokratis. Artinya antara pria dan wanita, ibu dan bapak harus ada kesepahaman dan kesepakatan dalam tugas-tugas mereka. Dari kedua tesis ini, Ainun Habibie berkeyakinan bahwa perempuan memiliki peluang dan kesempatan untuk tampil sebagai faktor yang berpengaruh dalam perencanaan keluarga menuju. Memang ada beberapa pendapat yang menyatakan bahwa pendidikan memainkan peran dalam proses membentuk keluarga sakinah dan sejahtera. Seorang wanita/ibu yang terdidik pastilah memiliki kelebihan adaptif tertentu, namun pembentukan

${ }^{21}$ Salkind NJ, Theoris of Human Development (New York: John Wiley \& Sons, 1985) h. 20. 
keluarga sakinah tidak identik dan tidak ditentukan oleh tinggi rendahnya tingkat pendidikan, semakin tinggi tinggi tingkat pendidikan seseorang tidak otomatis ia dapat menciptakan keluarga sakinah, ada faktor lain selain pendidikan seperti system sosial dan nilai-nilai budaya. $^{22}$

\section{Faktor Lingkungan.}

Teori pembelajaran sosial menyatakan bahwa seorang anak mempelajari perasaan, perilaku, dan perasaan melalui pengamatan kepada lebih dari satu model, teori ini menekankan kepada pentingnya pengaruh suatu lingkungan kepada perilaku anak dengan cara mengamati orang lain di dalam lingkungan tersebut. Perkembangan individu terjadi dalam suatu system budaya yang luas dimana individu berkembang dengan mengamati orang lain dan terlibat dalam aktivitas bersama dengan mereka. Teori perkembangan individu memandang bahwa perkembangan individu terjadi ketika individu secara aktif membangun standar perilaku melalui pengamatan terhadap orang lain. ${ }^{23}$

Teori pembelajaran sosial di atas secara tidak langsung mengatakan bahwa lingkungan dapat mempengaruhi gaya dan perilkau seseorang termasuk cara berpakaian (berjilbab). Ada dua macam lingkungan yang dapat berpotensi mempengaruhi cara berjilbab mahasiswi IQT: pertama lingkungan masyarakat di dusun mereka dan kedua lingkungan masyarakat kampus.

a. Lingkungan masyarakat tempat tinggal (dusun). Masyarakat dusun tidak memiliki pengaruh yang terlalu signifikan terhadap cara berjilbab mahasiswa IQT. Dari 10 respoden yang diwawancarai hampir menjawab bahwa mereka tidak peduli dengan lingkungan di dusun mereka, menurut peneliti hal ini terjadi karena mahasiswi IQT jarang bergaul dengan masyarakat di dusun disebabkan mereka kuliah di tempat yang pada umumnya jauh dari kampung/dusun sehingga interaksi jarang terjadi. Adapun keadaan masyarakat di dusun/kampung mahasiswi IQT bermacam-macam, ada yang religius dan sebaliknya. Bahkan salah satu responden mengatakan bahwa di dusunnya memakai jilbab merupakan suatu yang dianggap oleh masyarakat kurang baik karena melihat satu contoh yang tidak baik dari perempuan berjilbab lalu megeneralisir semua perempuan berjilbab. ${ }^{24}$

\footnotetext{
${ }^{22}$ Ainun Habibie, Membinangkan Feminisme: Refleksi Muslimah atas Peran Sosial kaum Wanita (Bandung: Pustaka Hidayah, 1997) h. 221-223.

${ }^{23}$ Salkind NJ, Theoris of Human Development. h. 20.

${ }^{24}$ Memang apabila kita lacak banyak argumentasi yang kontradiktif di dalam sumber ajaran Islam mengenai derajat wanita di tengah-tengah masyarakat, sangat familiar bagi kita bahwa ada hadis yang berkata "surga berada di bawah telapak kaki ibu”, dalam hadis lain juga dikatakan ketika ditanyakan kepada Nabi siapakah orang pertama yang harus dihormati?, Nabi menjawab “ibumu”. Meski demikian kesulitan muncul ketika seseorang menemukan hadis lain yang diriwayatkan oleh Bukhari dan al-Tirmizi yang menegaskan bahwa suatu masyarakat tidak akan pernah mencapai
} 
b. Lingkungan kampus. Lingkungan ini bisa dibagi menjadi tiga: pertama lingkungan perkulliahan, kedua lingkungan kos, ketiga lingkungan organisasi. Untuk yang pertama sangat memberikan pengaruh, hampir seluruh responden mengatakan bahwa interaksi mereka dengan teman-teman di IQT memberikan dampak positif kepada cara mereka berjilbab, hal ini karena hampir semua mahasiswi di IQT memakai jilbab baik di dalam kampus maupun di luar. Tapi untuk dosen belum memberikan pengaruh karena kebanyakan dari mereka mengatakan dosen pada umumnya tidak memberikan komentar tentang pakaian mereka. Kebanyakan mahasiswi IQT tinggal di kos yang bercampur dengan mahasisi dari fakultas yang lain, banyak dari mereka yang hanya memakai jilbab ketika di kampus saja, namun hal itu tidak berpengaruh kepada mahasiswi IQT, di kos mereka hidup sesuai dengan kenyamanan berpakaian masing-masing individu. Adapun organisasi yang ada di kampus cukup memberikan pengaruh kepada mahasiswi IQT dalam tata cara berjilbab, pada umumnya mahasiswi yang aktif di dalam organisasi kampus baik internal maupun eksternal lebih termotivasi dalam berjilbab, hal ini menunjukkan bahwa organisasi di UIN Raden Fatah tidak hanya memerikan dampak positif dalam bidang akademis, tapi juga akhlak, kepribadian, dan sopan santun. Dari uraian di atas peneliti melihat perlu adanya perhatian dari pihak Uniersitas kepada lingkungan kampus agar lebih baik dan kondusif, Kampus dengan lingkungan yang positif tidak hanya memungkinkan mahasiswa untuk mempelajari kemampuan akademik, tetapi juga gaya hidup (cara berpakaian) dan keterampilan sosial (empati dan kontrol diri) yang diperlukan untuk sukses di dalam kehidupan. Lingkungan kampus yang terdiri atas seperangkat kondisi seperti lingkungan dan tempat baru, pengalaman baru dengan teman, dosen, pegawai tata usaha kampus dan lainnya dapat mempengaruhi cara dan gaya hidup seorang mahasiswa. Bahkan menurut beberapa pakar, lingkungan kampus/sekolah yang

posisi puncak selama di pimpin oleh wanita, hadis-hadis semacam ini dipandang oleh sebagian kalangan amat sangat merendahkan derajat perempuan. Ungkapan kontradiktif lainnya dapat kita temukan di dalam Alquran, dimana dalam salah satu ayat Alquran membuat pernyataan adanya kesamaan derajat antara kaum pria dan wanita seperti QS al-Hujrat: 13, namun pada ayat lainnya Alquran juga menjelaskan kedudukan wanita berada di bawah kaum pria seperti yang terdapat dalam QS al-Nisa': 34. Memang secara akademik pendapat tersebut salah dan bisa diberikan penjelasannya secara rasional arguimentatif dengan menggunakan ilmu tafsir, namun masyarakat yang hidup di pedesaan kadangkadang tidak menerima informasi yang benar tentang ajaran tersebut. Ketidakjelasan informasi mengenai ajaran tersebut membuat ada sebagian masyarakat yang memandang tidak perlu untuk mengikuti ajaran Islam dan mengaplikasikannya dalam kehidupan keluarga mereka, dan jilbab termasuk salah satu ajaran yang dianggap tidak perlu bagi sebagian masyarakat. Lihat Atho Mudzahar, Islam dan Humanisme (Yogyakarta: Pustaka Pelajar, 2007) h. 121-122 
positif terbukti dapat menurunkan risiko terjadinya kekerasan di kampus, menurunkan permasalahan perilaku, dan meningkatkan tingkat kehadiran mahasiswa di kampus tersebut.

\section{Faktor Media.}

Media berpengaruh besar kepada cara berjilbab mahasiswi IQT, dari 10 responden yang diwawancarai hampir semua memperhatikan warna dan motif dalam memakai jilbab, baik yang berjilbab dalam maupun tidak, perhatian terhadapa warna jilbab sedik banyak merujuk kepada media baik cetak maupun elektronik.Dari hasil wawancara dengan 10 responden, peneliti menemukan bahwa sedikit banyaknya media mempengaruhi cara berjilbab mereka, kehadiran teknologi di tengah-tengah kita membawa informasi tentang berbagai hal termasuk jilbab, hampir semua dari responden memiliki ketertarikan terhadap warna dan motif jilbab yang tentu menyesuaikan dengan perkembangan zaman yang merujuk kepada media. Tapi pengaruh media di kalangan mahasiswi IQT hanya sebatas menjadi informasi tambahan dalam memilih jilbab, bukan menjadikan mereka berperilaku konsumtif.

Pada saat ini gaya hidup konsumtif dapat melanda siapa saja termasuk mahasiswa, mahasiswa yang seharusnya menambah pengetahuan, keterampilan, dan kegiatan yang positif untuk menunjang masa depan mereka, tetapi banyak dari gaya kehidupan kampus telah memberi gaya hidup khas pada mahasiswa dan terjadi artikulasi sosial budaya tinggi dalam mempertahankan prestise dari masing-masing individu. Saat ini banyak mahasiswa yang berlebihan dalam berpakaian, menggunakan uang secara berlebihan dan tidak sesuai dengan kebutuhan. Kampus yang seharusnya digunakan untuk tempat mencari ilmu pengetahuan digunakan sebagai ajang pamer penampilan. Seseorang bisa dikatakan konsumtif apabila membeli barang yang tidak sesuai dengan kebutuhan dan pertimbangan yang rasional, kriteria prilaku konsumtif adalah:

1. Membeli produk karena modelnya menarik.

2. Membeli produk demi menjaga penampilan dan gengsi.

3. Membeli produk atas dasar pertimbangan harga (bukan atas dasar kegunaan dan manfaatnya).

4. Membeli produk hanya sekedar untuk menjaga simbol status.

5. Memakai produk atas dasar konformitas terhadap model yang mengiklankan. ${ }^{25}$

Kebanyakan dari mereka membeli jilbab hanya di pasar dan toko-toko tradisional dan walaupun ada yang membeli di online shop itu hanya sebatas untuk kemudahan bertransaksi

${ }^{25}$ Budianto Hartato, Jilbab dan Trend Media (Jakarta: PPS UIN Syarif Hidayatullah, 2012) h. 84. 
dan banyaknya pilihan jilbab yang menurut mereka sesuai dengan anjuran Islam (jilbab syar'i). oleh karena itu peneliti berpendapat media memberikan pengaruh terhadap cara berjilbab mahasiswi IQT namun tidak menjadikan mereka berperilaku konsumtif-negatif, sifat konsumtif yang ditunjukkan oleh mahasiswi IQT adalah hal yang wajar dan sesuai dengan prinsip-prinsip dasar ekonomi Islam, berikut adalah karakteristik konsumsi perspektif ekonomi Islam:

1. Konsumsi bukan aktifitas tanpa batas, ia dibatasi oleh sifat halal dan haram yang ditentukan oleh agama, sebagaiman firman Allah SWT dalam QS. Al-Maidah: 87 "hai orang-orang yang beriman, janganlah kamu haramkan apa-apa yang baik yang telah Allah halalkan terhadapmu, dan janganlah kamu melampaui batas, sesungguhnya Allah tidak menyukai orang-orang yang melampaui batas”.

2. Konsumen yang rasional senantiasa membeli barang yang sesuai dengan kebutuhan jasmani dan rohani, cara seperti itu dapat menuntun mereka kepada keseimbangan hidup yang memang menuntut keseimbangan kerja dari seluruh potensi yang ada, mengingat terdapat hal di luar sisi ekonomi yang dibutuhkan untuk berkembang.

3. Menjaga keseimbangan konsumsi dengan bergerak antara ambang batas bawah dan ambang batas atas dari dalam ruang gerak konsumsi yang diperbolehkan oleh ajaran Islam. Pada ambang batas bawah seseorang akan cenderung bersifat bakhil dan kikir, sedangkan di ambang batas bawah seseorang akan cenderung bersifat sombong dan berlebih-lebihan sebagaimana firman Allah dalam QS. Al-Furqan: 67 “dan orang-orang yang apabila membelanjakan harta mereka tidak berlebih-lebihan, dan tidak pula (kikir), dan (pembelanjaan itu) adalah di tengah-tengah antara yang demikian”.

4. Memperhatikan prioritas konsumsi antara yang dharuriyah, hajjiyah, dan takmiliyah. Dharuruyah adalah komuditas yang mampu memenuhi komuditas yang paling mendasar bagi konsumen. Hajjiyah adalah komuditas yang dapat menghilangkan kesulitan dan relatif berbeda antara konsumen satu dan yang lainnya. Takmiliyah adalah komuditi pelengkap yang dalam penggunaannya tidak boleh melebihi dua komuditi sebelumnya. ${ }^{26}$

\section{Faktor Pemahaman Pribadi.}

Pemahaman seseorang tentang makna jilbab berpengaruh pada cara mereka berjilbab. Orang yang memahami bahwa memakai jilbab adalah salah satu perintah agama kepada perempuan muslim untuk menutup aurat, maka ia akan memakai jilbab sejauh ketaatannya 
terhadap perintah agama. Aplikasinya mungkin berbeda sejauh pemahamannya tentang apaapa saja yang dimaksud dengan aurat itu. Perempuan yang menganggap wajah merupakan aurat akan memakai penutup wajah (cadar), perempuan yang menganggap aurat adalah seluruh anggota badan kecuali wajah dan kedua telapak tangan akan memakai jilbab tanpa cadar, bahkan ada perempuan yang tidak berjilbab karena pemahamannya tentang menutup aurat tidak wajib, mereka berangggapan "yang penting hatinya berjilbab" sehingga cukup berpakaian sopan dan tidak perlu memakai jilbab. Fenomena-fenomena seperti ini banyak ditemui di tengah masyarakat, sehingga bisa dikatakan bahwa cara berjilbab seorang perempuan muslim dipengaruhi oleh pemahamannya tentang makna dan kegunaan jilbab itu sendiri.

Pada umumnya, mahasisi IQT memahami jilbab sebagai sebuah perintah Allah kepada semua perempuan muslim (tanpa terkecuali), ini berarti bahwa berjilbab adalah sebuah kewajiban. Pada umumnya, pemahaman tentang kewajiban berjilbab tumbuh dalam pikiran mahasiswi sebelum mereka masuk ke prodi IQT, dari 10 responden yang diwawancari hanya 1 responden yang mengatkan bahwa mereka tahu kewajiban berjilbab pada saat masuk ke IQT, pemahaman itu berasal dari berbagai macam sumber, ada yang dari orang tua, keluarga jauh, kakak, ayuk, dan guru sewaktu mereka masih berada di bangku SMA/sederajat. Tapi ada satu point penting yang peneliti dapatkan adalah bahwa dengan masuknya mereka ke IQT membuat pemahaman mereka tentang jilbab selama ini menjadi lebih positif.

\section{E. Kesimpulan.}

Mahasiswi IQT adalah manusia sosial yang tidak lepas dari pengaruh pihak lain dalam berbagai hal, termasuk dalam berjillbab. Sama dengan mahasiswi di prodi-prodi lain, ada keragaman dalam cara mereka memahami dan mengimplementasikan jilbab. Keberagaman itu disebabkan pengaruh baik dari dalam maupun dari luar diri mereka. Dinamika cara berjilbab tidak bisa dinafikan karena mereka memiliki historis, kultur, dan struktur yang berbeda-beda. IQT sebagai sebuah prodi yang fokus mempelajari Alquran dan tafsirnya memberikan mereka pandangan positif tentang makna dan tujuan berjilbab. Walaupun tidak terlalu besar namun sangat berate bagi mereka untuk menjadi pribadi yang lebih baik.

\section{DAFTAR PUSTAKA}

Abu Zaid, Bakar bin 'Abdullah. Menjaga Kehormatan terj. Gunaim Ihsan. Jakarta: As-Shofwa, 2003

${ }^{26}$ Bagoes Dhanardhoni DKK. Makalah Konsep Konsumsi dan Perilaku Konsumen dalam Ekonomi Islam 
Bagoes Dhanardhoni DKK. Makalah Konsep Konsumsi dan Perilaku Konsumen dalam Ekonomi Islam. Jakarta: UIN Syarif Hidayatullah, 2009.

Dahlan, Abdul Aziz Ensiklopedi Hukum Islam. Jakarta: Ichtiar Baru, 1993.

El Guindi, Fadwa. Jilbab; Antara Kesalehan, Kesopanan dan Perlawanan. Jakarta: Serambi, 2008.

Habibie, Ainun. Membinangkan Feminisme: Refleksi Muslimah atas Peran Sosial kaum Wanita. Bandung: Pustaka Hidayah, 1997.

Hakim, Ali Hosein. Membela Perempuan: Menakar Feminisme dengan Nalar Agama (Jakarta: alHuda, 2005

Hartato, Budianto. Jilbab dan Trend Media. Jakarta: PPS UIN Syarif Hidayatullah, 2012.

Shihab, Quraish. Jilbab pakaian wanita Muslimah. Jakarta, Lentera Hati, 2014.

Shihab, Quraish. Wawasan Al-Qur'an. Bandung: Mizan, 1997

Siaw, Felix Yuk Berhijab! Hijab tanpa nanti, Taat tanpa Tapi. Bandung: Mizan, 2013.

Kurzman, Charlez. Wacana Islam Liberal. Jakarta: Paramadina, 2003.

Kusumayadi.; Amir Taufik, Enam Puluh Satu Tanya Jawab Mengenai Jilbab. Kuala Lumpur: Pustaka Jasmin, 1989.

Mudzahar, Atho. Islam dan Humanisme Yogyakarta: Pustaka Pelajar, 2007.

Qardhawi, Yusuf Fatwa-Fatwa Kontemporer terj. Abdul Hayyie. Jakarta: Gema Insani Press, 2001.

Ramadhan al-Buthi, Muhammad said. Perempuan: Dalam Pandangan Barat dan Islam Terj. Nuruddin. Yogyakarta, Suluh Press, 2005.

Salkind NJ, Theoris of Human Development. New York: John Wiley \& Sons, 1985.

Shahrur, Muhammad. al-Kitab wa al-Qur'an: Qira'ah Mu'ashirah. Kairo dan Damaskus: Sina lil alNasr, 1992.

Yafie, Alie. Menggagas Fiqh Sosial dari soal lingkungan hidup, asuransi hingga ukhuwah. Jakarta: Mizan, 1994. 